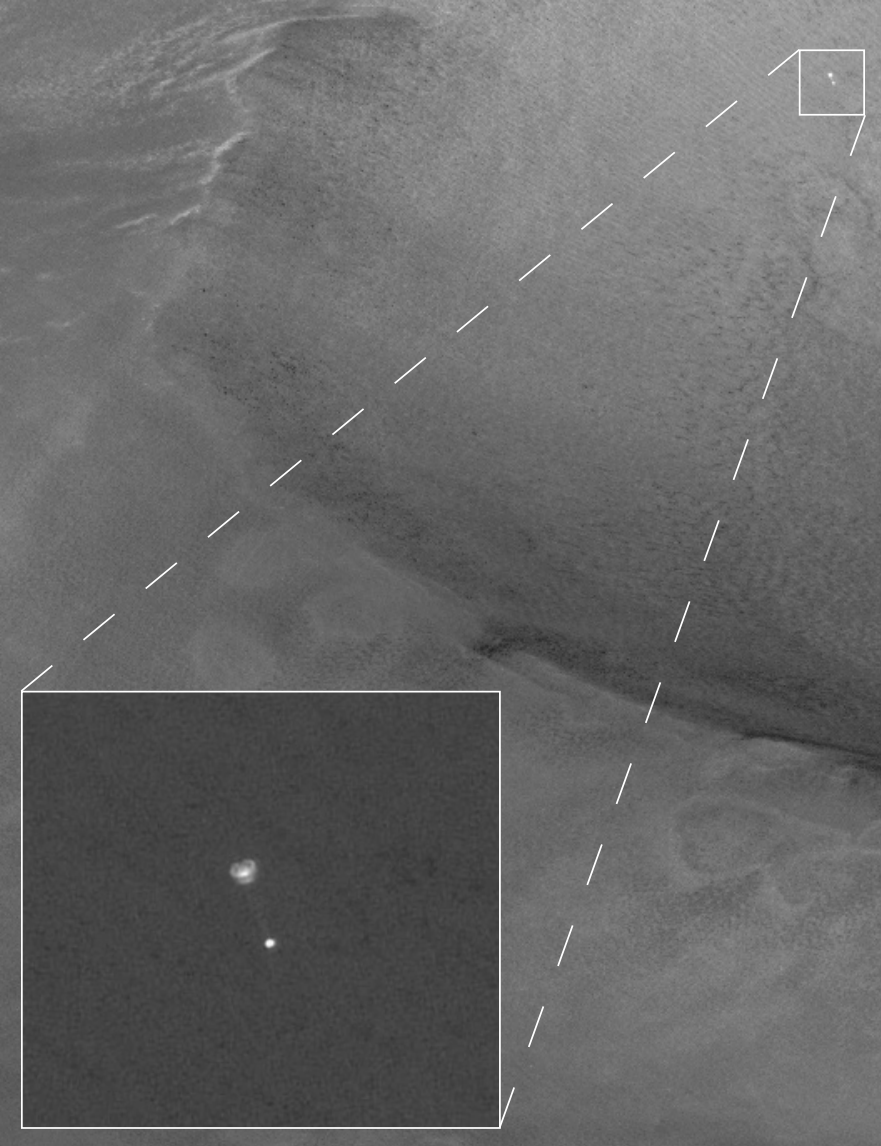

\title{
STRANGER IN A STRANGE
}




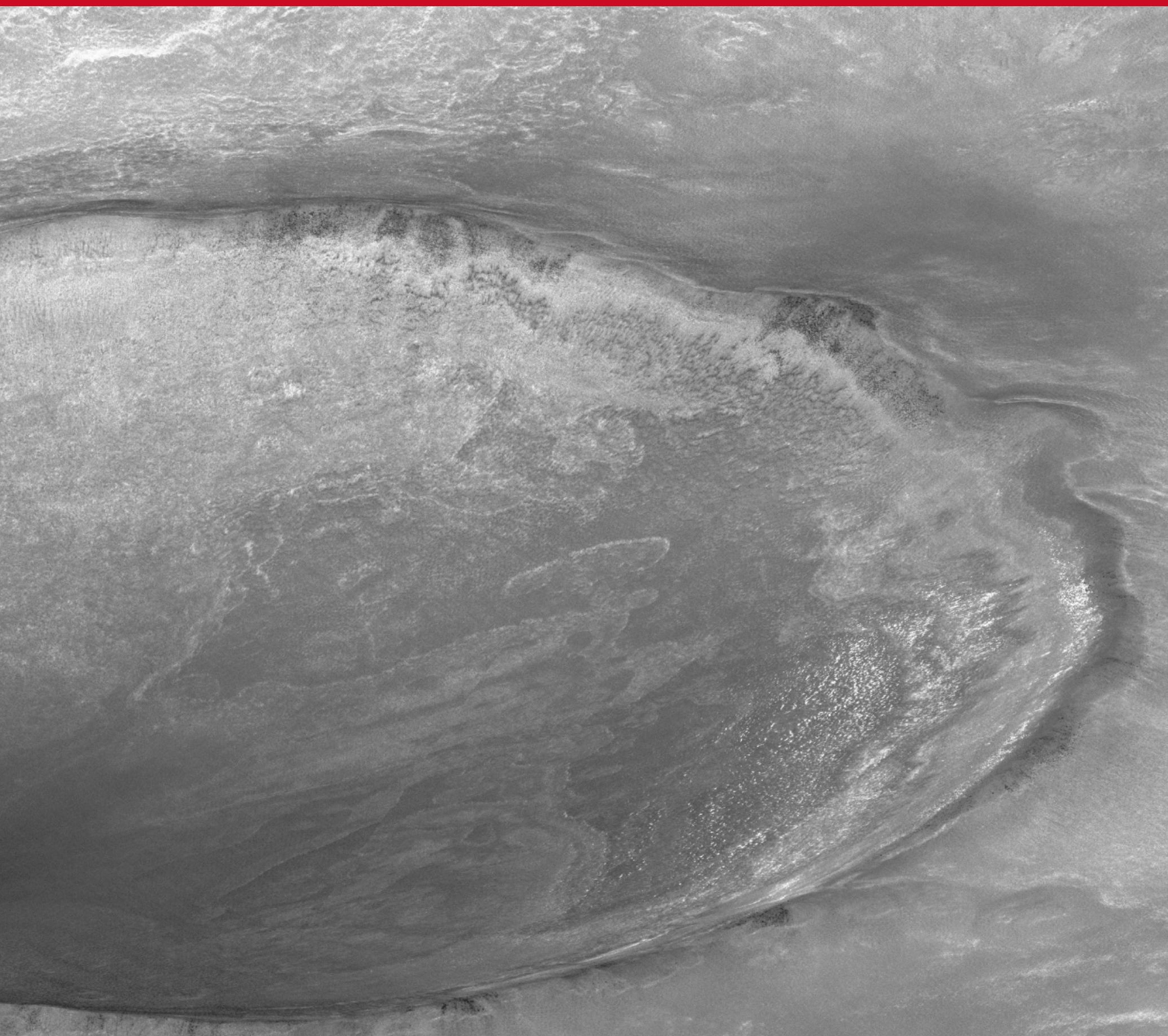

